\title{
Las finanzas personales de los millennials
}

\section{Por: Paul Granados}

Máster en Finanzas y Máster en Dirección de Empresas Catedrático-Investigador de la Universidad Centroamericana José Simeón Cañas (UCA)

pgranados@uca.edu.sv

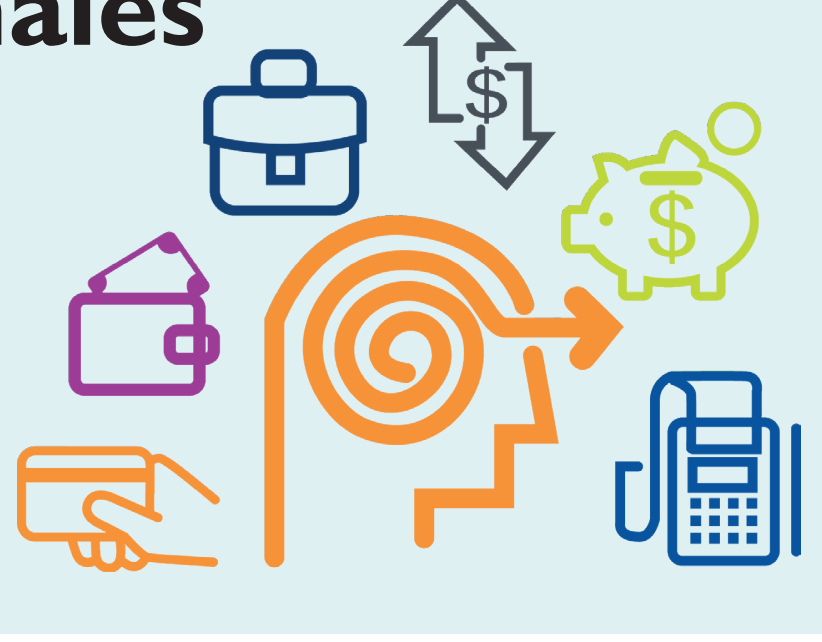

pre se pueden hacer pausas o cambios en el camino, "pero se necesita conocer el punto de partida y el destino final al que se quiere llegar".

\section{Diversificación de los ingresos.}

El entorno económico que le tocó vivir a esta generación es distinta a otras generaciones. Los mercados actuales son más competitivos, los ingresos son cada vez más limitados y los gastos cada vez más elevados. Si quieres empezar a "vivir como siempre haz soñado", es importantísimo empezar a construir múltiples fuentes de ingresos.

\section{Las deudas.}

Según el estudio de PWC, el $81 \%$ de los millennials tiene por lo menos una deuda a largo plazo. El $54 \%$ de los encuestados mostró preocupación cuando se les preguntó sobre su habilidad para manejar su deuda. El $53 \%$ tiene las tarjetas de crédito sobre girada y el $50 \%$ no podría atender un imprevisto si se le presentara en este momento. Las tarjetas de crédito son herramientas de financiamiento muy buenas si se utilizan de una manera adecuada, pero es importante tener claro que no son dinero extra, como dice Nathan W. Morris "Cada vez que pides prestado dinero, estas robando dinero a tu futuro".

\section{Fondo de retiro.}

Según el estudio de PWC, los millennials sacrifican sus ahorros para el retiro. Del $36 \%$ que tienen una cuenta para el retiro, el $31 \%$ ha solicitado un crédito o ha tomado dinero de ese fondo de retiro. 
Si ponemos en perspectiva que en la actualidad aproximadamente el $85 \%$ de los adultos mayores no se llegan a pensionar y termina dependiendo de sus hijos o viviendo en pobreza extrema, se agudiza el problema para la generación millennials por su pensamiento de "no tener hijos", ¿quién los va a mantener?, sólo queda la variable pobreza extrema. El pensamiento millennials vuelve más compleja la situación de la que en la actualidad viven los adultos mayores de otras generaciones.

\section{Aprender de un experto.}

A pesar de la problemática financiera en la que se encuentra esta generación, según el estudio de PWC, sólo el $12 \%$ busca ayuda sobre el manejo de deuda y el $27 \%$ sobre ahorro y retiro, eso significa que el $88 \%$ de los millennials no buscan ayuda financiera, evitan pensar en el problema y se abstraen de la realidad financiera en la que viven.
La buena noticia es que estos cinco puntos presentados como una debilidad en los millennials se pueden convertir en oportunidades y fortaleza, aprender a manejar las finanzas personales podría convertirse en ese tan anhelado estilo de vida que se desea, lo único que se necesita es tener el deseo genuino de aprender, tomarse el tiempo para leer acerca de finanzas personales en libros, revistas especializadas, sitios o blogs es un buen principio, agendar citas "de dinero" contigo mismo y dedicar algunas horas a administrar las finanzas personales es lo que convertirá esas debilidades en puntos fuertes. Cuanto más se conozco de nuestras propias finanzas, mayor confianza habrá para administrar el dinero en el largo plazo.

Si necesitas más ayuda, considera contratar a un coach financiero que te ayude a crear un plan para alcanzar tus metas. La realidad depende de lo que se haga ahora, recuerda ipara vivir mejor educación financiera!

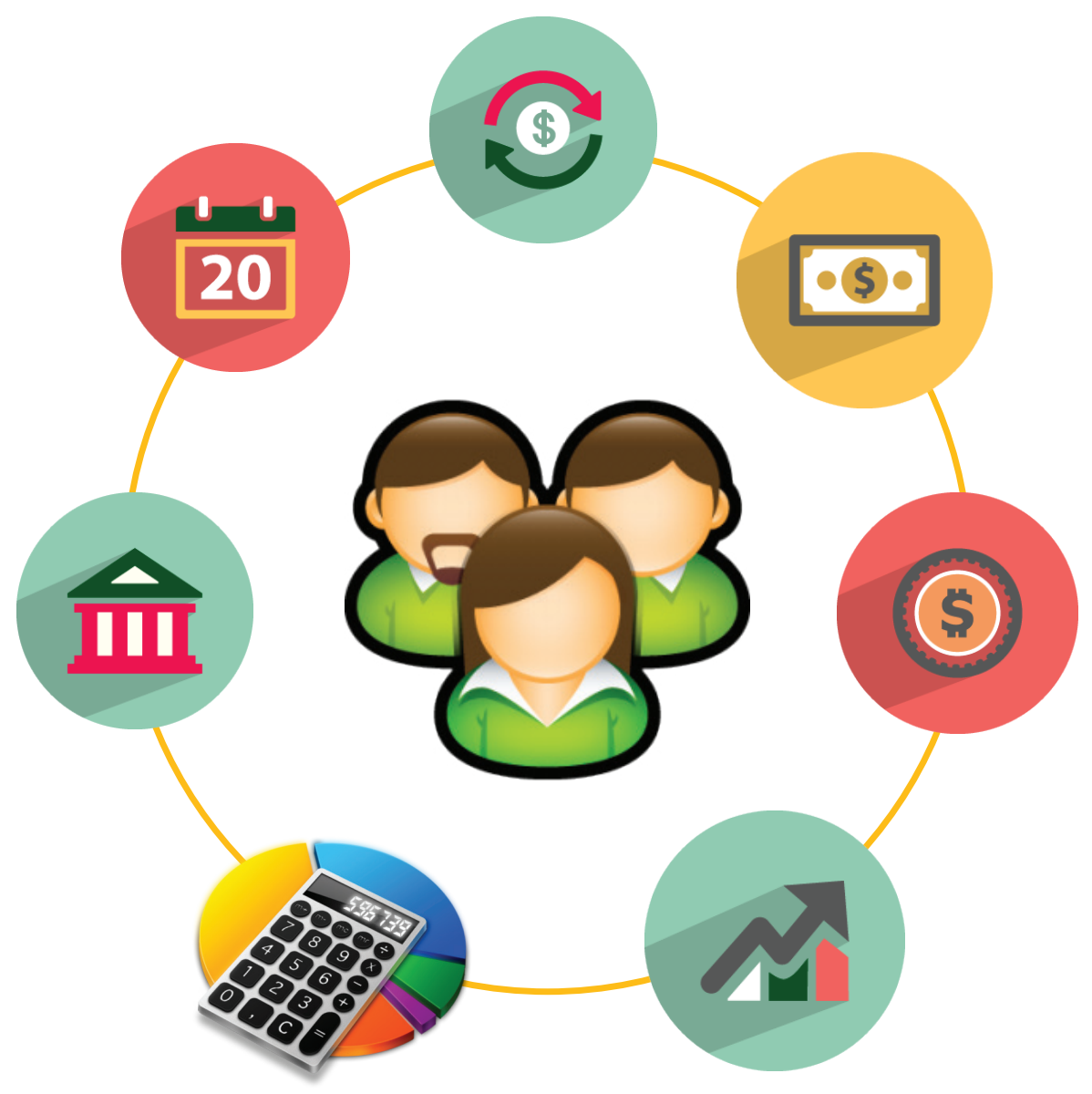

